\title{
Village Savings and Loan Associations Instrumental in Enhancing Women' Socioeconomic Empowerment in Rwanda
}

\author{
Dr. Isaboke Peter Kennedy Nyataya", PhD \\ Senior Lecturer and Director of Academic Affairs and Quality Assurance, University of Tourism, Technology \\ and Business Studies, Rwanda
}

*Corresponding Author: Dr. Isaboke Peter Kennedy Nyataya, Senior Lecturer and Director of Academic Affairs and Quality Assurance, University of Tourism, Technology and Business Studies, Rwanda

\begin{abstract}
Village Savings and Loan Association (VSLA) is a group of people who save together and take small loans from those savings The present study was on contributions Village Savings and Loan Associations(VSLAs)are generally, making directed towards the enhancement of women' socio-economic empowerment in Rwanda. For proper and adequate understanding of the subject under the present investigation, VSLAs operating in Nyamata and Rilima Sectors of Bugesera District of Rwanda, were chosen and taken to serve as case studies. In Rwanda, the female population is than that of male population. The Fin Scope Survey Rwanda 2016,noted that the prevailing gender differences in the country could be viewed in terms of education, social, economic income and health status. The main objective of this study is to identify the contributions of Village Savings and Loan Associations on women' socio-economic empowerment in the selected areas for the study by assessing the level of socio-economic status of women as beneficiaries after joining their respective VSLAs, besides, identifying services provided by the VSLAs aimed at ensuring women' socio economic empowerment in the district. The researcher adopted cross-section research design for the present study. The target population of the study comprised officials of World Relief Rwanda, women perceived have been or are being empowered by VSLAs in the sectors of Nyamata and Rilima, Representatives drawn from the local government, Bugesera District. The total population was then found to be 2292 people from which the representative sample size of the study chosen. The Yamane Formula (1967) was applied in the determination of the representative sample size of 96 respondents. Questionnaire method and interview method were used in the collection of the needed. The collected data were then analysed through the use of SPSS (Statistical Package for Socio science) Version16. It was found that 93\% of the respondents had no medical insurance before but acquired them soon after joining their respective VSLAs. Women's Purchasing power a economic indicator was less before and it improved after joining the VSLAs and this was claim put forward by $97 \%$ of the respondents. It was observed that the VSLAs covered in the study in a significant way, have contributed towards women' socio-economic empowerment in the area: through their various activities such as social funds provided, saving facilities, easy accessibility of basic health insurance as well as payment of school fees for their members' children, among others.
\end{abstract}

Keywords: Village Saving/Loan Associations, Enhance, Women, Socio-Economic Empowerment

\section{INTRODUCTION AND BACKGROUND OF THE RESEARCH PROBLEM}

World all over, women's participation in decision making, for many centuries now, to large extent, has been low and this has denied them their deserved space to enable them to speak, be heard and hence, receive recognition at local level, national level and global level as well. Women's all round participation is the order of the day in the present society. For the aforesaid to take place, institutions need to initiate and implement policies that tend to favour and protect women that can lead to the achievement of gender equality. Women's role and active participation in agriculture and agriculture related activities, alongside with their unpaid family work have remained invisible and hence, not portraying the true and positive image of women in the male-dominated societies. In the formal sector, too, wages paid to women more often that not have been found to be low compared to those paid to the men counterparts. At the same time, women are assigned low scale jobs and excluded from collective bargaining due to their limited number and are mostly are contracted. Besides, insecurity and harassment, too, do prevent them from spending adequate time outside their homes with a view to enhancing their incomes. 
At the beginning of the present century, as noted (UNIFEM,2004), Germany laid the foundation for women to advance in all economic spheres and the nation including government, non-profit organisations and associations. The private sector succeeded in addressing the principal obstacles that prevented women's economic empowerment. Village Savings and Loan Associations (VSLAs) model is one of the recent most approaches employed with a view to providing sustainable financial services to the rural people who happen to have less or no access to the formal financial services. The approach was introduced by the CARE in Niger in 1991 and was directed towards not only the empowerment of the vulnerable people but also to uplift them. The approach has become popular and taken to be appropriate and hence, different organisations and African countries, too, have adopted the approach, Rwanda inclusive. Developing countries, in general, a huge number of their rural people served by informal financial services, for instance, in Rwanda, about seventy two percent ( $72 \%$ of) of her adult population benefit from such services(Republic of Rwanda Government Gazette No.02 and 10/02, 2011).

Village savings is viewed as economic development approach that contributes to the well-being of rural societies. By facilitating savings and access to small loans, savings Groups enable community members to plan ahead, cope with household emergencies, develop their livelihoods and invest in the health and education of their children (Gasper, 2004).Savings Groups are used in relatively stable urban or rural contexts with limited or no financial services available for them. Village Savings Groups members are formed by members of a given community living, to a large extent, below the poverty line, who have limited or no access to financial services. The groups are formed on the basis of trust and ability to commit to small regular savings and are said to be effective if the members are drawn from the most vulnerable communities and families. It is worth noting that more often than not women are found to be trapped in the vicious cycle of poverty even if they are employed though they seen to be quite independent in their status and role in their respective families. Women feel that due to their economic support, a great deal of positive change is witnessed in the families. These relate to the material change as well as change in the attitude of their family members and hence, enabling them to feel that, they, now, $\mathrm{n}$ have better bargaining powers in decision making in their families and command some respect from them. However, in general, on social domain a woman observed to occupy low status which is coupled with biased cultural practices and weak social infrastructures. As noted by Kuppusamy (2010), The said factors have added to women's miseries for decades and left no room for empowerment of women in decision making even in the case of their own life.

The empowerment of women, as noted (World Bank,2012), is a national as well as a global challenge. It is a fact that the question of women's emancipation, empowerment, development and welfare has its many inter-connections, which are deeply rooted in various other factors such as socio-economic conditions, customs and traditions prevalent in society, nature of exploitation, nature of political systems, political culture, political socialization, political progress and global environment. However, issues regarding women empowerment are deeply with the active political involvement and participation from the grassroots level political institutions to the apex decision making institutions. Women often belong to the most vulnerable group in poor countries and are generally more financially excluded due to poor access to formal employment and to assets that can be used as collateral. Malawi, one of the poorest countries in the world is one such country in Africa with limited access to financial services to the rural population. By providing small loans, saving facilities and insurance to a good number of saving groups (SGs) have been noticed to provide the poor with access to financial services, taken for grant in the more developed countries. Village Savings and Loan Associations (VSLAs) is an approach of microfinance that lets groups of members save and borrow together, reaching the rural poor, aspointed out by Gasper( 2004). He further, examined the relationship between microfinance and empowerment in Pakistan by using five indicators to test empowerment: the ability to decide on child health, education, selection of spouses of children, purchase of basic goods and decision of household savings.

In Rwanda, policies have been formulated and are being implemented for ensuring gender mainstreaming with a view to introducing appropriate interventions that can help improve livelihoods and reduce poverty for women and their families, ensuring equal access to fair employment practices, credit, assets, and economic benefits. As result, the Government of Rwanda, has put in place legal frameworks that facilitate the formation of national women council to serve as forum through which women can exchange not only ideas on national issues but also on the overall development of the country. 


\subsection{Statement of the Problem}

The number of women, in Rwanda, today, is higher than that of men. The FinScope Rwanda in 2016, identified the gender differences witnessed in the country to be in terms of education, social, economic income, health status. The gender difference are due to a number of factors include structural determinants of financial inclusion such as lack of employment opportunities, lower income levels and lower levels of education((GoR,2011),

The present research work aimed at highlighting the key problems encountered by women of Nyamata and Rilima Sectors of Bugesera District as the result of the nineteen ninety four (1994) genocide committed against the Tutsi. Besides, the study at understanding the role played by the Village Savings and Loan Associations operating in the area formed with the facilitation of the World Relief Rwanda, with a view to socially and economically empowers women.

\subsection{Objective of the Study}

The overall objective of the study was to identify the contribution of Village Savings and Loan Associations towards socio-economic empowerment of women of Nyamata and Rilima Sectors of Bugesera District, Rwanda. Besides, seeking to understand the challenges the associations are faced with while carrying out their respective activities.

\subsection{Significance of the Study}

Through the study, for instance, the present researcher, not only acquired new knowledge on the role the VSLAs are playing in the area aimed at enhancement of women' socio-economic empowerment but also gained new skills on how to find practical solutions to particular problems. The findings might enable women beneficiaries to have a better understanding of the central role the VSLAs are presently playing in their lives and how they can gain more benefits through their involvement and active participation in their programmes and activities. The study will not only, to some extent, increase the level of knowledge of World Relief Rwanda on VSLAs' contribution toward women' socio economic empowerment in the area but also enable to improve upon as appropriate approach that can be adopted by other institutions, interested parties and stakeholders of VSLAs in general. The study, too, serves as base for future researchers on the present subject investigated and other related subjects. In addition, Rwanda Government is by all means likely to reap big from the findings of the study in terms of having a more understanding on the role VSLAs are playing in Bugesera District which can be replicated by other districts in the country especially in socio-economic empowerment of women. Hence, this can facilitate the Government in its strategic plans that can fasten the processes directed towards socioeconomic wellbeing of women by way of committing and offering more supportive services VSLAs.

\subsection{Limitations}

The study covered only VSLAs formed and operating in Rilima and Nyamata Sectors of Bugesera District selected on the basis of the long term impact brought by on women of the area through the genocide of 1994, which, to a large degree helped in the disempowerment of women survivors in particular. Hence, its findings will be applicable to the sectors studies. However, the effect of spill overs may not be ruled out for knowledge on VSLA activities/services are not only local but national and international as well.

\subsection{Scope}

The study assessed the contribution of Village Savings and Loan Associations on women socioeconomic empowerment in the selected area and covered the period 2013-2017.

The study focused on terms and conditions set by VSLAwhen providing sustainable financial services for the people who have less or no access to the formal financial services.

\section{LITERATURE REVIEW}

\subsection{Village Savings and Loans Associations (VSLAs)}

Village Savings and Loans Associations (VSLAs) are thought to play a critical role in bringing financial services to rural areas of developing countries, where access to formal financial services is typically very limited as pointed out by Teoh(2007).It is observed that majority of the world's poor 
lacks access to formal financial services. World Bank Report (2012)estimated that about 2.5 billion people had no access to formal financial services. Further, it noted that lack of access to reliable financial services may negatively affect welfare, economic or health, people may be unable to get sufficient capital together to invest in profitable economic activities. The promotion of the groups led to an improvement in financial inclusion, household business outcomes and women's empowerment. The formal as well as informal financial sectors continue to increase the access to formal financial services. However, the offering of such services to the rural poor is costly and a great number of them remain unbanked. It is again, observed that without formal financial services such as credit and savings products, it can be difficult for the rural poor to afford major expenses, invest in their farms or businesses or even pay for the unexpected events such as illnesses or funerals as pinpoited by Teoh ( 2007).Village Savings and Loan Associations (VSLAs) have served as powerful tools for enabling millions of women to access loans not only in setting up small businesses but also have improved quality of their life. VSLAs provide a unique platform for trust and solidarity among women who are the foundation on which to build societal empowerment. Evidence has shown that VSLAs have contributed significantly to the increment of household income and improvements in food security, health status or children's access to education (World Bank, 2012). It is noted that lack of access to and control over resources are the major obstacles towards women's political participation and widely, argued that, women's economic empowerment can play a key role in increasing women's participation in the political sphere. Having their own incomes, women become more independent, increase their self-esteem, grow their social capital and become more confident in moving into public spaces. However, other barriers such as restrictive social norms present a further challenge to women's participation, as indicated by Agarwal(2005).Further,he observed that women reported increased level of self-confidence and self-esteem due to better self-reliance from participating in saving. Many talked about having been shy and soft-spoken but through the demands of active participation in regular weekly saving group meetings, the women learned to express themselves. Women reported greater knowledge of saving and business management, how to diversify into more products that are profitable. They learned new social and leadership skills from interacting with women and men SG members. Women's and men's social solidarity and mutual problem solving in the group structure improved social relationships among and between women and men. Married women and men and single women now socialized together amicably, whereas before the SGs, there would have been tensions over single women taking away husbands or influencing married women to be unfaithful. Female heads of households (FHHs) talked about their improved social and economic status and strengthened social relations. Besides, a good number of women became leaders for the first time and role models for other women.

\subsubsection{Purpose of Village Savings and Loans Associations (VSLAs)}

Pilar (2001), define savings as the creation of assets of all types. In this approach, savings can resemble to credit, which provides financing for the purchase of assets. Perhaps the most frequent conception of savings is as a tool for cash flow management, helping the saver bridge gaps of consumption and income with extra liquidity. Lastly, savings can be thought of as a buffer against risk, a resource resembling to an insurance claim that can help mitigate the effects of unpredictable crises.

Savings for asset creation: An individuals' savings consists of an amount and type of assets that allow an individual to purchase an asset (Rutherford, 2000). Capital assets are often expensive and they include housing, land, or machinery for use in a business. Importantly, these assets can eventually be converted into less tangible goods as well. Housing may be used as collateral for debts, land can be rented to others, and capital brings an expected increase in income if used properly. Intangible assets range even wider and may include education, health, or community life events such as weddings and funerals. Savings for cash flow management: Saving needs not necessarily asset but also involves the accumulation of income over time. Instead, it is possible to think of savings as an instrument to help the poor manage regular expenditures that cannot easily be paid for out of pocket. Whether savings are for known or unknown needs, consumption smoothing, may at different times leave account balances high, low, or nonexistent (Graham and Wright, 2002). Savings for risk management: According to Zeller (2000), the necessity of saving helps to avoid bankruptcy in the face of unforeseen massive expenditures or losses. Expenditures in this context mean large hospital bills, the need to rebuild a home after a flood, or helping relatives get back on their feet. Losses could 
be the failure of a crop after a poor rainy season, the failure of a business investment, or the sudden disappearance of a large debtor. In the case of expenditures, the critical period for savings is before the event in which an individual must exercise restraint in order to accumulate enough balance to cover an impending expenditure. In the case of a loss, the period of restraint comes after the event, as the individual must use saving reserves to cover expected income that has been lost.

Savings and economic development: Savings and economic development are closely related to each other. The relationship between the individual savings and economic growth has been assessed by various economists many times. It is generally believed that the level of individual (businesses and households) saving can have a big impact on the performance of an economy. There are many aspects of savings affecting the economy growth. Fundamentally, the people's savings are the main domestic sources of funds for capital investment in infrastructure, education, technology etc. Which are necessary for the growth in economy and individual business? Besides, higher levels of savings allow a larger portion of people's overall debt to be financed by financial intermediaries and have a positive impact on economy and its growth in the country (Ricardo, 2010). The relationship between the individual savings and economic growth of business people depends on the form of savings. In practice, the following are the basic forms of people's savings: accumulation of savings in the form of investment in durable business of people's goods, which has positive effect on economic as well as business development because it stimulates the production of consumer goods as well as investment demand; Investments in securities-which lead to the increase in capital of the issuers and at the same stimulates investment demand;Keeping money in bank deposits-which gives the banks new capital that they can lend out for loans and credits and will stimulate these institutions and produce a profit for them. Keeping money in a sock or a money belt-the form of saving is considered not important for economic growth on one hand and on the other hand, analysts fear that rising rates of people saving can hamper the economic recovery. Consumer expenditures are such an important component of aggregate demand that even lead to small decline in consumption and could have a noticeable effect on economy as pointed out by Sinha and Sinha (2007). They further note that in such conditions, more saving means less consumption and at the same time less consumer demand. It means that increased household saving could slow economic growth. Some economists believe that in relationship between savings and economic growth bidirectional causality should be more prevalent. May opine that the causality flows from saving to economic growth. The causality from savings to economic growth is supported from the argument that domestic savings determine domestic investments. However, in many countries the causality goes in the opposite direction. Higher savings are the consequence of higher economic growth.

\subsubsection{Factors Influencing Saving}

Income level: Income level is the main source of saving. Saving is positively related with income that is the higher the income tends to be the higher level of saving and vice-versa. Hence, possibility of saving increases as income people's increases. When income becomes very low, then people cannot save for they cannot cover even their minimum basic requirement (Katib, 2013). Price Level: General Price level is also an important determinant of saving. When price rises, the amount of saving starts to decline to those people who are mainly depending on fixed income. Rate of Interest: Rate of interest is also an important determination of saving. It takes positive relation with saving that is, the higher the rate of interest, the higher level of saving and vice-versa. When the rate of interest increases people reduce their normal consumption and try to save. On the contrary, people used to save less, when the rate of interest decreases. Fiscal Policy of Government: The Income and expenditure policy and process of government also changes the ratio of saving in a country. The government can adopt two types of fiscal policies that is expansion and contraction fiscal year. Expansionary fiscal policy helps to rise saving, where government reduced rate of tax and increases government expenditure. They all help to increase income and when income increases then saving automatically increases. On the other hand, the contraction fiscal policy reduces the ratio of saving, where government imposes high tax system and also reduces the government expenditure. Distribution of income: Distribution of income is one of the responsible factors to determine the level of savings. In some countries and societies, income is distributed equally whereas in some sectors income is distributed unequally. In case of unequal distribution of income, few people have large amount of income. So they can save more because most of their wants are already fulfilled and they have low MPC. As a result additional consumption of these people with additional income does 
not increase rapidly. Therefore, it can be said that consumption is typically the function of poor and saving is typically the function of rich people (Athukorala and Sen, 2003). Social Security System: Social security system is based on economic growth and development. The rate of saving will be very low in the place where various social security system are fully developed like old age pension, medical insurance, unemployment allowance etc. When social and economic security systems are appropriately found then people will not be worried about their future and try to enjoy with higher level of consumption, which reduce saving (Magaji and Yahaya, 2010).

\subsubsection{Challenges Women Face in Village Saving Groups}

The poorly-resourced women are more often than not are not able to join village saving groups (VSGs) due to the fact that they cannot afford to pay the membership fees. Another major challenge they face is that till date the majority of women and men still believe that men are the rightful heads of households and final decision makers. Women are expected to obey them if they want to access and use the saved money. Some married women reported that their husbands were using their wives' savings and loans for their own interests (Kashuliza,2002 Leacok(2001), argued that conflict of interest in couples can occur and pose a risk of gender-based violence (GBV). In some cases, women might challenge their husbands on what to spend the loan on. In other situations, a woman's strategy might be to remain silent about what she wanted to do with a loan to avoid her husband getting angry. Female village saving group members may be unable to pay the loan back as result of social marginalisation from other members or husbands. Leacok (ibid), has noted that women earn less than men because of their lower educational achievements; lower business know-how; lower social status; and unequal access to credit, technology, land and labor. These gender gaps create inequalities in women and men's negotiating power over resources and deny women the same opportunities to access education or training in order to compete on equal terms. Some women do own and control lucrative assets in their own right, however, the majority is constrained by traditional gender norms and low educational attainments and, hence, find themselves in a lower "fallback position" to which they cannot use for influencing decision making processes within and outside the households.

\subsubsection{Women Empowerment}

To Young and Kate (2008), empowerment means management practice of sharing information, rewards, and power with employees or group of inspired people so that they can take initiative and make decisions to solve problems and improve service and performance. Empowerment is based on the idea that giving employees skills, resources, authority, opportunity, motivation, as well as holding them responsible and accountable for outcomes of their actions, which contribute to their competences and satisfactions. Further, points out that female empowerment require governments and wider institutions taking responsibility for creating the right conditions for women and girls to exercise their rights. For instance, Malawi, has put some important gender policies in place. The national development plan, the Malawian Growth and Development Strategy, makes commitments to address gender inequalities. In rural Malawi, customary laws and practices tend to override formal government policies protecting women's equal rights. Customary law legitimizes discriminatory practices such as polygamy, early marriage, wife inheritance, gender-based violence, and property grabbing in both matrilineal and matrilineal communities as noted by White (2001)

\section{a) Women's Economic Empowerment}

According to White(2001), investing in women's economic empowerment sets a direct path towards gender equality, poverty eradication and inclusive economic growth. Women make enormous contributions to economies, whether in businesses, on farms, as entrepreneurs or employees, or by doing unpaid care work at home. But they also remain disproportionately affected by poverty, discrimination and exploitation. Gender discrimination means women often end up in insecure, lowwage jobs, and constitute a small minority of those in senior positions. It curtails access to economic assets such as land and loans. It also limits participation in shaping economic and social policies. And, because women perform the bulk of household work, they often have little time left to pursue economic opportunities. The concern for women in poverty alleviation efforts is important because women continue to be the most disadvantaged group. Globally, the issue of women and poverty requires a special consideration because women and girls of poor rural households bear a disproportionally high share of the burden of poverty. This is manifested in the nature of women's 
work in agriculture which expose them to certain health hazards; time devoted to work and rest by men and women in rural areas; women's unequal access and control over cash and its implication in poverty alleviation and the nature of women's domestic and reproductive work (Young and Kate, 2008). In measuring poverty or wealth of women, the level of their access to and control over resources must be considered. This is because from a gender perspective, power over resources is a key concept on poverty. This view has led to the realization by many people that, without a critical analysis of gender relationships in society and overcoming the constraints that mitigate against women, poverty alleviation programmes will continue to benefit more women than men (Sunday News, Tanzania, No. 31153, 2004). Poverty affects households as a whole, gender division of labour and women's responsibilities for household welfare make women bear a disproportionate burden in alleviating poverty. For example, trade liberalization policy in Tanzania removed price control and subsidies. This forced women to look for ways of earning incomes to meet the rising prices of food items. The policy has affected women more because they are the immediate food suppliers at the household level (Meillassovx, 2005). Poverty is perceived and experienced differently by men, women and social classes. The controller of resources has more power in poverty alleviation and thus poverty alleviation policies and programmes need to be implemented to ensure gender sensitive. In relating poverty to gender and social groups, gender analysis, manifestations of poverty are important and must be associated with inequalities in gender within social class. The World Bank suggests the strategies for incorporating women in economic development are implemented and the need of studying and considering gender relations in as far as access to and control of resources for alleviation of poverty are concerned.

Women play reproductive roles of hindrance towards poverty alleviation. Observation on this issue show that woman's reproductive responsibilities related to child birth and child care that cause absenteeism and lower participation in income generating activities and in employment for those women who have wage employment (World Bank, 2012).Poverty must be based on a sound analysis of the different situations of men and women especially in terms of power over resources. This is because access to and control over resources is one of the major constraints facing women in the development. Meillassovx, define empowerment as a psychological state, a sense of competence, control and entitlement that allows one to pursue concrete activities aimed at becoming powerful. Empowerment acts as increasing an individuals' ability to act more effectively without endangering or reducing others' power or ability to do so. Empowerment is a process that increases the capacity of the disempowered to act on their own behalf and to analyze and understand their problems, to recognize their ability to act on their own behalf and increase their power and control over the resources necessary for sustainable and dignified life. According to UN Women (2011), women's empowerment is a strategy with an outcome goal of reduced gender inequality and disparity between men and women, subsequently attaining increased development and social transformation. To empower women means, making women realize their production and other social roles potential in the society. This means increasing her access to employment opportunities in all spheres of economic activities through which she can earn a living, satisfy her basic needs for existence; improving women's management and agricultural production capacities in the informal sector; developing entrepreneurial skills so as to increase their initiatives to start up IGAs on their own; having access to training, to technical skills, to factors and means of production and to marketing skills. One of the constraints on women's business is sectorial segregation. Throughout the world women are most likely to be found in food production and processing, beauty services, and child care. Women empowerment strategies could address involvement of women in the context of other areas. Meillassovx (2005), discussed how constraints on time, spatial mobility, domestic responsibilities and decision making could be approached in a process of empowerment. Meillassovx, too, came up with factors which prevent women into larger business and these include low technology and lack of collateral for credit as the main constraints. He recommends economic empowerment which would allow such women to attend training and increase their ability to buy equipment necessary for expanding their businesses. Furthermore, self-confidence, determination and positive attitudes are also problems facing women entrepreneurs. These constraints can only be eliminated through empowerment from and within Village Saving and Loan Association. The mobility; economic security; ability to make small purchases; ability to make larger purchases; involvement in major household decisions; freedom from domination within the family; political and legal awareness and involvement in political campaigning and protests were seen as indicators of women empowerment in 
both social and economic status. Boitumelo (2005), pinpointed that financial groups do not discriminate against women. However, few women have are starting receive credit from such institutions even if they are considered as lack of collateral, knowledge on how to process the loans, and be discouraged with long distances of banking services. In discussing the impact of credit schemes on women, (World Bank, 2012) argues that although it is commonly assumed that credit itself is empowering even though it is a liability. In order for the liability to be empowering, it must be a means of economic development. The evidence suggests that the provision of credit does not challenge the traditional division of labour thereby resulting into increased male predominance. (Athukorala and Sen, 2003), looked at the control women retained over loans received from the Grameen Bank, a large government scheme and a small NGO, all in Bangladesh. Credit has to be issued to women as a means of economic development. Empowerment of women on the other hand is and has been an articulated goal of development strategies. It is assumed that the borrower is the one being empowered. It has further been observed that credit is a key element in economic empowerment because it assures the productivity of the enterprise being financed (Boitumelo, 2005). However, a credit scheme may fail to empower women entrepreneurs depending on how it is managed. The observation is that, no amount of credit even at the most reasonable rates, can guarantee higher productivity, or incomes among credit recipients unless it is accompanied by other packages such as infrastructure, agricultural subsidies, supportive services, credit policies as well as the management of the credit scheme itself. This shows that credit alone cannot guarantee economic empowerment. To Sallehand Osman (2007), procedures used by credit schemes may cause a negative impact to loan recipients and hence fail to empower them. For example, procedures and formulation by the lending group or institution might make the borrower to lose opportunities which would have enabled him/her to raise productivity. Such opportunities include changes of prices and borrower's enthusiasm for the whole venture and changes of weather for agricultural credit. The concern over loan repayment sometimes has a negative impact on the whole empowerment process where some officials of credit schemes take a patronising view of the loan recipients. The stated procedures enable recipient to pay rather than on rigorous enforcement of relatively simple sanctions which will discourage the recipient not to pay. Where such a patronizing view prevails it may psychologically disempowering credit recipients instead of empowering them.

\section{b) Women Social-Economic and Political Empowerment}

According to World Bank (2012), empowerment of women extends beyond economic and social aspects; it also includes political empowerment. This means increasing access of women to democratization process, governance, politics and decision making; women's access to and management of natural resources; to land tenure and food security; to sustainable shelter and other issues of environmental interests. However, this study will limit itself to women's empowerment socially and economically by investigating the contribution of Village Saving and Loan Association on socio-economic women empowerment. For women to be fully empowered, it means increasing their access to more income which can form a basis to improve their productivity. It also means getting access to education, employment and health services. It further means strengthening their position in terms of access to and ownership of productive resources and equality in decision making powers (Agarwal, 2005). Men's attitude and respect to women must also be transformed to reflect improved communication channels and women's involvement in decision making. The level to which they have control over their resources and the dignity or respect they command also show improvement in gender relations.

\section{c) Women's Empowerment in Rwanda}

Rwanda's long-term development plan, as articulated in Vision 2020, seeks to transform Rwanda into a middle-income country by the year 2020. Developing an efficient, sound and inclusive financial sector is crucial to meeting the economic cluster targets of Vision 2020 and the Seven Year Government Plan (7YPG). Equally importantly, a sound and stable financial sector provides a foundation for the achievement of social and governance related objectives. Savings are the leading product type and one of the main drivers of financial inclusion for women in Rwanda. However, this category also shows the biggest gender differences, especially in terms of formal savings (MINECOFIN,2012).Women in Rwanda mainly reside in rural areas, are relatively young, with lower levels of education, depended on low and more irregular sources of income such as farming. Given 
that Rwanda's population is relatively young, with low levels of education, residing mostly in rural areas, and largely being dependent on irregular/low sources of income (agricultural), the overall level of financial inclusion is remarkably high. In 2016, only $14 \%$ of the female adult population in Rwanda (about 462,000) are financially excluded [compared to $10 \%$ of men], meaning they manage their financial lives without the use of any financial products or mechanisms external to their personal relationships ( Finscope Rwanda, 2012). Women empowerment and economic development are closely related: in one direction, development alone can play a major role in driving down inequality between men and women; in the other direction, empowering women may benefit development. Women's empowerment and economic development are closely interrelated. While development itself will bring about women's empowerment, empowering women will bring about changes in decision making, which will have a direct impact on development. Economic development alone is insufficient to ensure significant progress in important dimensions of women's empowerment. Women's empowerment leads to improvement in some aspects of children's welfare (health and nutrition, in particular), but, at the expense of others. Women and men traditionally engage in different roles along social norms and economic opportunities. This affects women's demand for different financial product and services. Women residing in rural areas, who are young (below 30 years of age) and older women (above the age of 50), with no or low levels of formal education, and those who generate an income from piece work or agricultural activities (including those receiving a salary from a farmer) seem to be most vulnerable in terms of financial inclusion and therefore should be given priority (Ibid).

\subsubsection{Social Status of Women}

With rapid economic development and the advent of the women's movement, the changing status of women received much attention around the world. With reference to Korean women the level of social status is based on development of new social roles with progressive and active attitudes, improved education and social participation (Kjaerby, 2009). Higher education is essential to improve women's status, because education changes women's attitudes deeply rooted in belief and tradition and thus helps them to socialize their children to share equal partnership in marriage and in society (ibid).Status of Women is often described in terms of their legal rights, education, economic independency, and empowerment, age at marriage, health, and fertility, as well as the roles she plays in her family and society. The status of women implies a comparison with the status of men, and is therefore a significant reflection of the level of social justice in the society. A study conducted by Kjaerby (2009), indicate that lack of power over their own decision-making has long been recognised as a barrier to improve women's sexual and reproductive health. The factors that determine the status as well as the fertility of women in Bangladesh are education, and empowerment, occupation of husband, residence and possession of items and religious beliefs and norms. World Bank( 2012), noted that educational attainment of women is generally considered a useful index of socioeconomic status as well as of the level of overall social sophistication, and therefore, it is inversely related to the desire for additional children and women's mean age at marriage. Education is a key determinant of the life style and status an individual enjoys in a society. It affects many aspects of life, including demographic and health behavior. Education through literacy provides access to wider source of information and a broader perspective. Education through socialisation process spread out social values and, modernisation and rationalism grow out of education.

\subsubsection{Economic Status of Women}

A study conducted in Pakistan with the partnership of ShirkatGah (NGO) by Women's Empowerment in Muslim Contexts (WEMC) project (2010), considers power as the driving force that excludes and marginalizes individuals and groups. (Farida, 2009), suggests that politics and religion are the real force which dis-empower women in the name of culture, religion and tradition and are capturing state power. The (UNIFEM, 2004), has drawn a framework of women's empowerment to develop seven principles which include: Leadership Promotes Gender Equality, Equal Opportunity, Inclusion and non-discrimination, Health, Safety and Freedom from Violence, Education and Training Enterprise Development in Supply Chain and Marketing Practices, Community Leadership and Engagement, Transparency Measuring and Reporting. It is clear that the women's empowerment is a broad and expanding concept which includes increasing women's equality in all spheres such as legal, political, economic and social. 
The economic well-being of women is often used as an indicator of the overall advancement of a society. Recently, jobs and earnings result of better wages is observed. Study conducted by(Ba, 2013), indicates that economic status of women is determined by involvement in small investments projects like business, agriculture, acquiring fixed assets like houses, etc. Through the promotion of entrepreneurship and managerial excellence, the International Centre for Entrepreneurship and Career Development (ECD) supports women in establishing micro, small and medium enterprises and this has created business formalization and provides an important foundation for the viability and economic development (Young and Kate, 2008). It has further been observed that credit is a key element in economic empowerment because it assures the productivity of the enterprise being financed (World Bank, 2012)

\subsection{VSLA's Role towards the Enhancement of Women' Socio Economic Status}

VSLAs, over a period of time have proven themselves to be very effective in accelerating growth and building local capacity. VSLA members have access to highly responsive and safe financial services, and this enables them to upscale economic activities, improve household health and welfare, acquire business skills, educate their children, and improve the quality of their social lives both within the family and the surrounding community (Rutherford, 2000). While many VSLA members already supplement their income with earnings from small-scale businesses activities, only a few have knowledge of - or experience in - saving and borrowing money for investing in businesses and other income generating activities. VSLA provides training creates long-term livelihood security by enabling members to select income generating activities suitable for their individual circumstances, to plan for a successful launch, and by ensuring that loan takers manage their businesses effectively so that the loans are repaid on time, income matches expectations and risks are kept within a manageable limit(World Bank, 2012).The rise of VSLAs has proved that poor people can fight poverty and improve their lives using their own resources but as the groups develop, new needs arise. VSLAs have proven to be very effective in accelerating growth and building local capacity. VSLA members have access to highly responsive and safe financial services, and this enables them to upscale economic activities, improve household health and welfare, acquire business skills, educate their children, and improve the quality of their social lives both within the family and the surrounding community (World Bank, 2012). A Village Savings and Loan Association (VSLA) is a group of people who save together and take small loans from those savings. The activities of the group run in cycles of one year, after which the accumulated savings and the loan profits are distributed back to members VSLA is a more transparent, structured and democratic version of the informal savings groups found in villages and slums in many parts of the developing world. Village Savings and Loans Associations (VSLAs) are thought to play a critical role in bringing financial services to rural areas of developing countries, where access to formal financial services is typically very limited (Agarwal, 2005).In Zanzibar, VSLAs have performed very well in producing useful and sustainable financial services to communities poorly served by other organisations. However, it is important to consider the relatively well-off socio economic status of the members especially the relatively high levels of secondary education (World Bank, 2012). Women' socioeconomic empowerment depends on both financial and non-financial forms of support service. In this research, authors like (Agarwal, 2005), empowering women need first be included $r$ in education, employment and health services as well as allowing her have ownership of productive resources but this author ignores women related weakness and home assignments which are limitations to their development process. In his analysis, he did not considers problems related to spokes persons, complicated administrative procedures in task related developmental activities and competition which most of women see as complication in their social working environment and this was seen as gap existing in this research. Many researchers like (Athukorala and Sen, 2003) they think that women empowerment is based on financial means of support where they assumed that the borrower is the one being empowered but researcher' observation criticize this because women empowerment need to be based on recognition of women in social working environment, enhancing them towards skills related trainings, education and allowing them to have experience at national and internal employment opportunities. The ignore that poor management can lead to loan repayment problem and other related risks financial. After certain observation of researcher for the current study about contribution of Village Savings and Loan Associations on women socio-economic empowerment, there still exists the gap between VSAL and women social economic empowerment. As solution to all gaps mentioned above, the nation, 
international countries, profit making organisation, nonprofit making organisation and policy makers need to encourage and promote women towards socio economic development through saving mobilisation, integrating them in social and economic working activities and inclusion in equitable and sustainable national development programs.

\section{RESEARCH DESIGN AND METHODOLOGY}

\subsection{Research Design}

Cross section research design was adopted for the present study.

\subsection{Target Population and Representative Sample Size}

The target population of the study was the officials of World Relief Rwanda, women beneficiaries of the VSLAs operating in Nyamata and Rilima Sectors of Bugesera District and selected representative of from the local government. Hence, 2292 was the total study population. Stratified random sampling technique was used in selecting the representatives of women beneficiaries in the selected sectors for the study. The Yamane Formula (1967) was then applied in the determination of the representative sample size. Hence, the representative sample size of the present study was 96 respondents, arrived at as shown below..

$$
\mathrm{n}=\frac{\mathbf{2 2 9 2}}{1+\mathbf{2 2 9 2}(0.1)^{2}}=\frac{\mathbf{2 2 9 2}}{1+22.92}=\frac{\mathbf{2 2 9 2}}{23.92}=95.8 \cong 96
$$

\subsubsection{Sources of Data}

Primary sources as well secondary sources of data were made use in the study. Primary data was obtained from the respondents through the use of questionnaires and interviews conducted with them by the present researcher. Secondary data was collected from various materials which included textbooks, journals, magazines, articles, reports and studies that have been carried out in this area before and internet articles.

\subsection{Methods of Data Collection}

Data were gathered from the selected respondents for the study through the use of methods mentioned below.

\subsubsection{Questionnaire Method}

Questionnaire method was used in obtaining the required data for the study from the officials of World Relief Rwanda and the local government officials selected and treated here as respondents for the study.

\subsubsection{Interview Method}

Interview method was used in collected data for the present study from the women beneficiaries of the VSLAs operating in Nyamata Sector and Rilima Sector of Bugesera District.

\subsection{Data Analysis}

Data collected for the study were analysed using SPSS (Statistical Package for Social Sciences) Version 16 through, frequencies, tables and percentages.

\section{FINDINGS}

Through the study it was noticed that the majority (47.9\%) of the respondents belonged to the agegroup $32-37$ while $27.1 \%$ of them were between $44-50$ years old. $19.8 \%$ of them were in the age group 38-43 while the remaining 5.2\% were above 50 years old. This then indicates that the VSLAs covered in the study are facilitating and helping young and active women. It was also noted that the majority $(85.4 \%)$ of the respondents were primary school educated.11.5\% of them are secondary certificate holders. Besides, it was observed that eighty two $(85.4 \%)$ of the respondents are married, eleven $(11.5 \%)$ were widows, demonstrating that the majority of the respondents covered were mature enough and were making use of the opportunities offered by the VSLAs in terms of productive activities and other developmental projects.3.1\% of the respondents were found to be single. The study revealed that $72.9 \%$ of the respondents had worked with the VSLAs for a period ranging between 4-5 years whereas $12.5 \%$ had worked with them for over a period of 5 years of 
experience.6.3\% of them had worked with them a period between 2-3 years while $7.3 \%$ a one year experience with VSLAs.

It was observed that eighty nine (93\%) of the respondents were able to acquire their health insurance for themselves and their easily for their children after joining VSLAs. In terms of nutrition, ninety two (92) of the respondents claimed that the support they are receiving through their respective VSLAs has led to their improved household nutritional status. The present researcher noted that the respondents' ability to pay school fees for their children was enhanced through the VSLAs, which also facilitated them in creating new businesses, as indicated by $99 \%$ of the respondents.98\% (94) of the respondents were of the view that they had gained their self-after being integrated into the social and economic development projects initiated by the VSLAs in the area. The study revealed that beneficiaries' savings increased tremendously after joining their respective VSLAs, as pointed out by the majority ,ninety five $(99 \%)$ ) of the respondents. In terms of productivity, it was noted that $93(97 \%)$ of the respondents indicated that the beneficiaries' productivity was low and so was their income before but went up soon after starting to receive support from the VSLAs. In addition, it was found that before becoming members, women were not involved in development projects, however, were abled to engage themselves in agriculture, trade, transport and livestock activities by VSLAs and this accelerated their incomes as confirmed by ninety five (99\%) of the respondents. Besides, it came to light that women's purchasing power improved through the support received from the VSLAs as strongly agreed upon by the ninety three( 97\%) of the respondents which made them able to initiate more income generating activities through they were able to satisfy their respective needs, which, then, generally, contributed towards their economic empowerment. The activities/programmes undertaken by the VSLAs in the selected area of study, which, to a large extent have contributed to women's economic empowerment, which included financial support extended to its beneficiaries.54.2\% of the respondents said that the amount of money ranging from 15,000 rwf to 20,000rwf, as stat up capital for their economic and economic related activities. ((99\%) of the respondents, too, indicated that the VSLAs facilitated them to increase their savings through their respective saving groups.

\section{CONCLUSION}

Research studies have brought to light the fact that, in general, women' status continue to be low dues to a number of factors notably cultural norms and belief systems, customary laws and access to land/property, household resource problems, decision making and powers problems, family responsibilities which limit their time and mobility constraints, which, in the long run, negatively impact socio-economic empowerment. Besides, insufficient support services, financial illiteracy and lack of self-reliance are viewed as other additional problems to women. The aforementioned situations have motivated researchers to direct their attention finding out which approaches can be appropriate and employed in empowering women both socially and economically through relevant support services that can enable them to be inclusive. Female empowerment requires governments and wider institutions taking responsibility in creating the right conditions for women to exercise their rights. The concern for women in poverty alleviation efforts is important due to that fact that women continue to be the most disadvantaged group. Globally, the issue of women and poverty requires a special consideration for women and girls in poor rural households bear a disproportionally high share of the burden of poverty. The rise of VSLAs has proven that poor people and women in particular, can fight poverty and improve their lives using their own available resources, however, as the groups develop, new needs arise. Besides, VSLAs have demonstrated themselves to be effective in building and enhancing local capacity and hence, accelerating growth in their respective areas of operation. VSLA members and beneficiaries have access to highly responsive and safe financial services, which have enabled them to upscale their economic activities, their improve household health and welfare, acquire business skills, educate their children and improve the quality of life of their families in particular and that of their communities and their surrounding environs. It was found that the VSLAs covered, in a significant way, have contributed towards women' socio-economic empowerment in the area, through their various activities such as social funds provided, saving facilities, easy accessibility of basic health insurance as well as payment of school fees for their members' children, among others. Besides, geographical location, government policies, local leadership, too, have influenced to women' social economic empowerment in the area covered under the present study. Through the study, too, it was realised that there was a clear relationship betweenVillage Savings and Loan Associations and 
women' socio-economic empowerment. Using Spearman's Correlation Analysis, that is, explained by 0.893 strong correlation which implication means that the VSLA support services exhibit direct positive and significant relationship with women' socio-economic empowerment in the area.

\section{RECOMMENDATIONS}

Beneficiaries of the VSLAs should be offered training and mentorship by relevant individuals or institutions on how to effectively and sufficiently manage available resources created through their respective saving groups, besides, they should encourage more of their fellow women to join VSLAs which can steer their social economic empowerment. They should make concerted efforts towards the establishment of cordial and development conscious relationships with both

World Relief-Rwanda and the local government who have all the potentials of identifying for them the available opportunities for investment that can help them to enhance their social- economic empowerment. Experts and experienced individuals can be handy in the provision of the need expertise in the running and management of savings groups.

World Relief Rwanda should replicate the number of VSLA groups under their support and facilitation to other sectors of the Bugesera District and intensify their services which can, then, in particular, serve as catalyst towards social and economic development of women in the area, with a view to reducing gender gap and gender inequality, hence, strengthening families.

There is need for the local government along side with its other partners to develop strategic guidelines that can be followed to ensure that women in the area are empowered socially and economically. Besides, the government should conduct frequent assessment to establish the nature and types of problems faced by women in their day-to-day endeavours and help in finding possible solutions to the identified problems. Timely procedures, organised and focused trainings for all women will not only be of benefit to women of Nyamata and Rilima Sector but also their counterparts in the neighbourhood as regards their social economic empowerment.

\section{REFERENCES}

[1] Agarwal, B. (2005). Rural Women and High Yielding Variety Rice Technology in IRRI (eds) Women in Rice Farming. Aldershot, : Gower Press.

[2] Athukorala, C. and Sen, K. ( 2003). The Determinants of Private Savings in India, World Development, 32(3),. India: World Development.

[3] Ba, S. (2013). Boao Forum Report on the Development of SMB Financing. SMB Financing.

[4] Bodenheimer, S. ( 1970). Dependency and Imperialism: . The roots of Latin American underdevelopment. (New York: NACLA), , pp. 49-53.

[5] Boitumelo, S. et al. (2005). Access to Credit for Non-Informal Micro-Enterprises in Botswana". Journal of Development Studies, Vol. 31, No.6, pp 42-76.

[6] Buvinic, M. (2003). "Promoting Women's Enterprises: What Africa can learn from Latin America" in Helmsing, A.H.J. and Th. Kolstee (eds) (1993) Small Scale Enterprises and Changing Policies,. London: IT Publications, pp. 295-307.

[7] Carlos, E., and Pilar C. (2001). Mexico Rural Finance: Savings Mobilisation Potential and Deposit Instruments in Marginal Areas. Washington, DC.: World Bank,.

[8] Chamber, Robert. . (1995). Poverty and Livelihoods : Whose Reality Counts ?dalam Uner Kirdar dan Leonard Silk (ed.). People : From Impoverishment to Empowerment. New York: University Press.

[9] Cook, P. (2000). Finance and Small Medium Enterprise development. Manchester: IDPM.

[10] Dos Santos, T. (1971). The Structure of Dependence. . Boston: Extending Horizons, , PP 225-233.

[11] Farida, S. (2009). Gender, religion and the pursuit of justice. New York: USA.

[12] Finscope Rwanda. (2012). Thematic report on women: Access to Finance. Kigali: Rwanda.

[13] Gasper, K. (2004). The women and children's health program and gender equity in Banchte Shekha,". Evaluation Report prepared for Ford Foundation, NORAD, and The Asia Foundation Donor Consortium,: Dhaka.

[14] Goldfrank, W. (1986). The World-System of Capitalism: Past, and Present. . Beverlly Hills, California: : SAGE.

[15] Graham A. and Wright. . (2002). Mobilising Savings. MicroSave-Africa Briefing Note . Nairobi, : Kenya. 
[16] Habermas, G. (1992). Theory of Social Communication. New York: : MacMillan,.

[17] Isaboke,P.K.N.(2017).Women's Development Through Voluntary Action,Lambert Academic Publishing

[18] Issahaku, H. (2011). Determinants of Savings and Investment in deprived District Capitals in Ghana. A case study of Nadowli in the Upper West Region of Ghana", Continental Journal of Social Science, 4(1), , $1-12$.

[19] Kabeer, N. (2005). Gender equality and women's empowerment: a critical analysis of the third millennium development goal, . New York: Gender and Development, 13.1, March 2005.

[20] Kashuliza, V. (2002 ). Agricultural Credit in Tanzania: Policy and Operational Problems of CRDB" Quarterly Review. No.4. Tanzania: CRDB Quarterly Review.

[21] Katib et al. (2013). Savings and Investment Behaviour of Bank Customers. Proceedings of World Business and Social Science Research Conference, (pp. 1-13.).

[22] Khan, A. (2008). Islamic microfinance: theory and practice. 19 streets south. Birmingham United Kingdom: : Islamic Relief Worldwide.

[23] Kjaerby, F. (2009). The Dynamic History of The Subordination of Women in Classless Societies. Paper no. $35 \mathrm{BW}$. New York: USA.

[24] Kuhn, L. (2002). Empowering woman through microfinance, UNIFORM. International journal of business management, $\mathrm{pp} 98-120$.

[25] Kuppusamy et al. (2010). Leadership Styles and Management Techniques: An Analysis of Malaysian Women Entrepreneurs, in Communications of the IBIMA, vol. 2010. Malaysia: IBIMA.

[26] Ministry of Finance and Economic Planning. (2003). Vision 2020. Government of Rwanda: Kigali.

[27] Leacok, E. (2001). Myths of Male Dominance,. New York: Monthly Rview Press.

[28] Lim,W \& Ting,D. (2009). Research Nethodology: a toolkit of sampling and data analysis technique for quantitative research. retrieved from http//www.grin.com.

[29] Magaji, S. and Yahaya, H. (2010). Portrait of low savings in Africa. Africa.

[30] Meillassovx, C. (2005). From production to Reproduction, A Marxist Approach to Economic Anthropology" Economy and Society. New York: USA.

[31] MINECOFIN . (2012). Public Financial Management Reform Strategy. Kigali,: Rwanda.

[32] NBR,. (2015). Microfinance activities in Rwanda. Rwanda: Kigali.

[33] Official Gazette of the Republic of Rwanda. (2011). Law no 02/2011 of 10/02/2011, determining the Responsibilities of the National Women's Council. Rwanda: Kigali: 10 February 2011.

[34] Opportunity Interational. (2012). Provision of microfinance services in the developing world. IL.Retrived fromhttp://www.Opportunity.org: Oak Brook,.

[35] Orodho, A. (2003). Essential of educational and Science Research method: Nairobi: Masola Publishers.

[36] Ricardo, H et al. (2010). The Global Gender Gap Report 2010,. World Economic Forum, , pp 42.

[37] Rutherford, S. (2000). The Poor and Their Money.Authoritative account of savings methods, practices, and values in the context of the financial lives of the poor. U.K.: London:.

[38] Rwanda Local Development Support Fund :RLDSF. (2011.). Vision 2020 Umurenge Programme, Rwanda Annual Report 2009/10. January 2011. Kigali: Rwanada.

[39] Salleh, Z. and Osman M. (2007). Goal Orientations and Typology of Women Entrepreneurs. Jurnal Kemanusiaan, vol. 10 , pp12-29.

[40] Secretariat, Pacific Islands Forum. (2012). Briefing Paper: Economic Empowerment of Women, . Kiribati, 2-4 July.: Forum Economic Ministers Meeting,.

[41] Shane, S. (2003). A general theory of entrepreneuship: The individual opportunities nexus. U K:: Edward Ellgar.

[42] SINHA D. and SINHA T, . (2007). Relationships among Household Saving, Public Saving, Corporate Saving and Economic Growth in India ,. India: Ritsumeikan Asia Pacific University,.

[43] Sunday News, Tanzania, No. 31153. (2004). Handeni Women in non-women activities" June 16, p. 7. Tanzania.

[44] Teoh, W.et al. (2007). Theorising a Framework of Factors Influencing Performance of Women Entrepreneurs in Malaysia. Journal of Asia Entrepreneurship and Sustainability, vol. 3, No. 2. , pp 97-108.

[45] UN Women. (2011). Progress of the World's Women 2011-2012: In Pursuit of Justice. New York : UN Women.

[46] UNIFEM:United Nations Development Fund for Women . (2004). Women's Empowerment Principles: Equality Means Business. New York:: USA.

International Journal of Research in Sociology and Anthropology (IJRSA) 
Village Savings and Loan Associations Instrumental in Enhancing Women' Socioeconomic Empowerment in Rwanda

[47] White, S. (2001). Evaluating the Impact of NGOs in Rural Poverty Alleviation,Bangladesh Country Study, ODI Working Paper No.50, London, . London: Overseas Development Institute.

[48] World Bank. (2012). World Development Report2012: Gender Equality and Development . Washington D.C.: World Bank.

[49] Young and Kate. (2008). Women and Economic Development: Local, Regional and National Planning Strategies. . Paris, : UNESCO, BERG Publishers.

[50] Zeller, Manfred, and Manohar S. (2000). Many Borrow, More Save, and All Insure: Implications for Food and Micro-finance Policy. New York.

Citation: Dr. Isaboke Peter Kennedy Nyataya. "Village Savings and Loan Associations Instrumental in Enhancing Women' Socioeconomic Empowerment in Rwanda" International Journal of Research in Sociology and Anthropology (IJRSA), vol 4, no. 3, 2018, pp. 42-56.doi:http://dx.doi.org/10.20431/2454-8677.0403005.

Copyright: (C) 2018 Authors. This is an open-access article distributed under the terms of the Creative Commons Attribution License, which permits unrestricted use, distribution, and reproduction in any medium, provided the original author and source are credited. 